\title{
Jesuit Business Education Model: In Search of a New Role for the Firm Based on Sustainability and Dignity
}

\author{
Ricardo Aguado ${ }^{1 *}$, Leire Alcañiz ${ }^{1}$, José Luis Retolaza ${ }^{1}$, Laura Albareda ${ }^{1}$
}

\begin{abstract}
Jesuit Universities have been training responsible professionals since the 16th century. Given this educational tradition, and in the face of the new challenges posed by the present-day social and economic situation, the Society of Jesus has started to implement the "Ledesma-Kolvenbach" educational paradigm in its higher education institutions. Instead of short-term profit maximization, the Ledesma-Kolvenbach model considers sustainability, human dignity and social well-being as key elements in business strategies. The objective of this paper is to propose a method capable of measuring the economic and social value generated by a firm managed in accordance with the four dimensions of the Ledesma-Kolvenbach model. The methodology is developed in three steps. In the first place, the authors explore the existing literature on the Ledesma-Kolvenbach model and its roots in Jesuit education. Secondly, they analyze the literature that studies the role of the firm from a neoclassical perspective, as well as other complementary or alternative approaches. In the third place, they present an empirical model that has already been tested in different organizations, designed to measure the social and economic value generated by firms. The main result of the paper is a method that can be used to measure the social and the economic value generated by firms, such that society, managers and public administrations have an operational tool to present and evaluate the economic and social performance of firms.
\end{abstract}

Keywords: Ledesma-Kolvenbach model; social value monetization; humanistic management; Jesuit business education

$21^{\text {st }}$ International Association of Jesuit Business Schools (IAJBS)

$18^{\text {th }}$ Colleagues in Jesuit Business Education (CJBE)

\section{Introduction}

In this paper we explore the emergence of a new educational model for executive education that is framed within the broader debate on a humanistic management educational paradigm (Dierksmeier, 2011) and, specifically, the in-depth debate that has unfolded in this regard at Jesuit universities in the last few decades. The objective is to adapt the Jesuit higher education system to construct a more sustainable, just, and faith-filled world (Society of Jesus, 2014). Since 1975, the Society of Jesus has redefined its mission as a service of faith and the promotion of justice. As a result, Jesuit higher education institutions have made great efforts to fulfill this mission and to incorporate a humanistic approach into the training of students, one that is based on profound individual and community self-reflection and self-awareness, social consciousness regarding human needs, and a commitment to get involved in social, environmental and economic issues, as well as the promotion of the common good, social justice, human dignity, and the spiritual experience of transcendence towards God, stressing the love of one's neighbors and hope for the poor and the needy (Society of Jesus, 2014, p. 19). This approach involves a deep reflection about the challenges facing higher education and business education today and the construction of a sustainable economy from the economic, environmental and social standpoints.

In line with this debate, we study the application of the new educational model proposed by Jesuit business schools to address people's social, individual and economic needs that may serve as a reference for the broader humanistic management educational paradigm under which the Ledesma-Kolvenbach model can be understood. In this article, we present an alternative educational model, known as the Ledesma-Kolvenbach model (Kolvenbach, 2001 and 2008). The model, which was developed by the former Superior General of the Society of Jesus, Peter-Hans Kolvenbach, in close collaboration with the Society of Jesus, incorporates the seminal ideas of the 16th-century Jesuit theologian and pedagogue Diego de Ledesma, adapting them to the present-day situation.

Many scholars today propose that new approaches should be incorporated into business and management education in order to grant legitimacy to the role of firms in society and to increase the level of social well-being that they create (Ghoshal, 2005). The new humanistic management educational paradigm proposed by various scholars (Dierksmeier, 2011; Pirson, 2014) is built on the core concept of human dignity and the promotion of justice, and concepts such as beneficiation, shared value, stakeholder approach, and the common good, along with innovation and competitiveness (Pirson, 2014). In their view, successful competitive firms create value for shareholders as well as for the rest of stakeholders, thereby legitimizing their role in society (Porter \& Kramer, 2011). This perspective is quite different from the classic homo economicus theory that is still the core microeconomic assumption underlying many business programs (Dierksmeier, 2011). On the other hand, this new view demands not only analytical skills, but also "soft" skills and the capacity to lead businesses towards sustainable competitiveness, while simultaneously contributing to the creation of a better world in terms of justice, social well-being and environmental sustainability (Aguado, Alcañiz \& Retolaza, 2015).

(1) Deusto Business School, University of Deusto, Bilbao (Spain)

*Corresponding author: ricardo.aguado@deusto.es 
According to neoclassical thought (the dominant economic paradigm), the goal of the firm is short-term profit maximization. This means that the theoretical objective of shareholders is automatically transformed into the firm's objective, and the interests of the rest of stakeholders are ignored. As a consequence, the main metrics used to measure the performance of a firm are focused on profits and, more specifically, short-term profits. However, these metrics do not guarantee that the activity of the firm is economically sustainable in the long term and, moreover, do not provide any information about the firm's social and environmental sustainability. A methodology is therefore needed to measure the social value (which includes environmental sustainability and the promotion of social well-being and human dignity) and the economic value generated by firms, such that society, managers and public administrations have an operational tool to present and evaluate the economic and social performance of firms.

The paper is divided into five sections, in addition to the conclusions. After this introductory section, in the second section we explain the Ledesma-Kolvenbach model as an alternative to the traditional homo economicus model in management education. In the third section, we discuss the role of the firm from traditional neoclassical thought to recent developments that address catholic humanism, human dignity and social well-being. In the fourth section we develop a new methodology designed to measure the total value (economic value plus social value) that the firm generates for all its stakeholders (shareholders, but also customers, employees, public administrations, and society at large).

\section{The Ledesma-Kolvenbach model}

The educational tradition of the Society of Jesus (SJ) dates back to the 16th century, as its founder (St. Ignatius of Loyola) emphasized education as a key element in the mission of the SJ. In fact, the Society of Jesus was founded in an academic environment, at the Sorbonne University in Paris. Instead of creating its own universities, the SJ originally sent its new members to existing universities to complete their higher education. In 1548, however, the Society of Jesus decided to become more involved in educational activities, as it realized that education was a privileged tool to transform, serve and help other people and society at large in a more efficient manner (Kovenbach, 2001). At present, education continues to be one of the most important engagements of the Society of Jesus.

At the beginning of the 21 st century, the Society of Jesus was serving 2.5 million students in 3,451 educational institutions in sixty-eight countries, including 202 higher education institutions, 404 secondary education schools, 79 vocational training institutes and 2,603 other educational centers in nineteen Latin American countries (Oraá, 2007, p. 31).

The reasons behind the Society of Jesus' involvement in higher education were explained by Diego de Ledesma in the late 16th century, and encompass four different categories (Society of Jesus, 1965). The first involves providing the students with the necessary technical skills and knowledge to excel in the professional field of their choice. The second establishes a link between the prosperity of individual students and the promotion of the common good. The third is a commitment to educate the whole person - body and spirit, intellect and emotion -, as every human being is considered to be connected to the rest of the human family and to the environment, while the last category provides a new window to a transcendental view of the human being, based on the Catholic tradition. By promoting these four objectives, Jesuits can make a positive contribution to both the students and society at large (Kolvenbach, 2001).

In the late 20th century and early 21 st century, the former Superior General of the Society of Jesus, P.H. Kolvenbach, in agreement with the Society of Jesus, started to develop an innovative discourse on education and, more specifically, higher education at Jesuit universities (Kolvenbach, 2008). He based his vision on Ledesma's statements, adapting them to the needs, demands and complexities of modern society. The so-called Ledesma-Kolvenbach model was intellectually developed primarily through lectures delivered at different universities: Santa Clara (USA), IQS-Barcelona (Spain), Namur (France) and Gregoriana/Georgetown-Rome (Italy, 2007). The current Superior General, Adolfo Nicolás, has endorsed the model and, in speeches given at the Ibero-American University in Mexico City (Nicolás, 2010) and the University of Deusto (Nicolás, 2011), stressed the challenges of globalization and the need to continue to support imagination, creativity and critical thinking in higher education.

The Ledesma-Kolvenbach ( $\mathrm{L}-\mathrm{K})$ model is deeply embedded in the Jesuit pedagogical tradition and clearly shows why the SJ invests so much effort in higher education. It is also rooted in the main principles of Catholic Social Thought: the preservation and promotion of human dignity, solidarity, and the common good. These principles may, of course, be shared by the larger community of humanist scholars, whether or not they adhere to any particular faith (Aguado \& Martínez, 2012).

The model takes into account the fact that universities are institutions which have their own objectives in terms of academic freedom and autonomy, but the SJ incorporates the promotion of human dignity, solidarity and the common good to the traditional goals of universities, as it believes that these values are perfectly compatible with their main tasks (Agúndez, 2008).

The model can be conceived as a quadruple helix composed of four basic dimensions: Utilitas (Utility), Iustitia (Justice), Humanitas (Humanism), and Fides (Faith). The first dimension is called Utilitas (Utility) and encompasses the necessary skills, knowledge and techniques that every student should develop in order to become an excellent professional. Society needs good professionals and Jesuit universities should fulfill this mission as best as possible. The two main tasks of universities, teaching and researching, should be guided by this principle. Thus, the actions of Jesuit business schools should be grounded in a desire to solve the main social problems of humankind, i.e. in the generation of wealth with a sustainable approach and the creation of a society that is respectful of human dignity. As a result, students will develop professional skills with the final goal of serving society and contributing to its improvement (Agúndez, 2008). 
The second dimension of the L-K model is called Iustitia (Justice). This means that the internal organization of Jesuit universities should be transparent and equitable, and that research activities should have a positive social outcome (Nicolás, 2010). On the other hand, teaching activities should present students with real social and economic problems, so that they learn to analyze reality in a critical manner and develop a personal sense of justice in relation to the disadvantaged (Kolvenbach, 2008). This dimension also includes the development of the necessary skills to become responsible citizens, capable of fulfilling their social and political duties, and making a positive contribution to national development and the common good. Universities should act as the critical conscience of society and, consequently, should train professionals with a leadership style that involves proficiency in their field, teamwork skills, and service to their organizations and the common good (Agúndez, 2008).

The third dimension is called Humanitas (Humanism) and represents a basic premise of the Ledesma-Kolvenbach model: the development of the whole human being, and not only the intellect, as it is conceived within a humanist framework that stresses the various dimensions of the human being. The humanitas dimension trains students to develop the necessary skills to solve professional tasks (both social and technical) and raise their level of awareness (in relation to themselves and to social and organizational problems), their level of compassion (so as not to ignore the condition of others), and their level of commitment to people, organizations, or social initiatives. In this respect, it is closely linked to the Declaration of Human Rights, human dignity, environmental sustainability and the pursuit of freedom and the common good. For this reason, Jesuit universities are open to collaborating with all persons sharing the same humanistic values (Florensa, 2008).

The fourth dimension is called Fides (Faith), and offers students the possibility to develop their spiritual life. Even though this dimension expresses the original identity of Jesuit universities, it is not the role of the university to proselytize, as this is not considered to be proper (Kolvenbach, 2001; Etxeberria, 2008) and, moreover, Jesuit universities are home to students with different faiths or no faith at all, and this must be respected. On the other hand, all human beings are capable of developing a spiritual dimension. Fides should try to enhance this dimension in all types of students. As far back as the ancient Greeks, Aristotle stated that every person has the same final goal: happiness (or subjective well-being). The pursuit of happiness stems from the fact that there is a difference between what a person is and what he or she would like to be. Our current global society conventionally offers three ways to fulfill this need: possessions, power and status. Ultimately, however, the acquisition of more material items or a higher status threatens to become an endless race, with no happiness in sight. The spiritual proposal of Jesuit universities, which is valid for all types of students, is quite different, as it involves focusing the goals and activities of the individual on other persons, activities or society at large. Instead of pursuing the maximization of self-interest, happiness will be achieved through cooperation and service to others (Miralles, 2008).
Naturally, the roots of this type of spirituality are to be found in Catholic humanism and the spiritual sources of the Society of Jesus (Society of Jesus, 2014). However, while the development of a spiritual dimension should be offered to all students, the introduction to Catholic or Jesuit spirituality should be offered on an optional basis only, outside the compulsory curriculum (Etxeberria, 2008).

\section{The goal of the firm: From profit maximization to social well-being}

At the microeconomic level, profit maximization has traditionally been the main objective for firms. This notion is not only shared by mainstream microeconomics, but by many academics in management studies as well (Jensen, 2002). In fact, economic rationality dictates that every economic actor (the individual, the firm) should try to maximize its own profit, following an egoistic pattern. As a result, those persons who do not follow it will be treated as irrational, while those firms that do not strive to obtain the maximum possible profit will simply be expelled from the competitive market. Ultimately, the entire economic system becomes amoral, because economic actors have only one possible behavior: following the maximization pattern. No ethical premises or moral inquiries are allowed; only profit maximization exists. Although this narrow view of the firm has had strong supporters (Jensen, 2002), it is questionable, as it leaves no room for human dignity inside the firm, since all its resources, including human resources, are treated as a means to achieve the only "rational" objective: short-term profit maximization.

Managers and management students who have studied the L-K model are expected to develop a broader view of the goals of the firm and its role in society. Firms have to be competitive, efficient and innovative, but, according to the L-K model, they should also get involved in a shared effort to make economic growth compatible with environmental sustainability and social well-being (social sustainability).

Sustainable development has started to be treated not only at the national and international levels, but at the level of the firm as well (Porter \& Kramer, 2011). Consumers increasingly demand that businesses manufacture and offer eco-friendly products and services. At the same time, a growing number of shareholders demand that corporations behave in a responsible manner towards the environment and the stakeholders, while communities are increasingly active in their demands to reduce the negative externalities that affect them. In this new vision that is arising, short-term profit maximization should not be the only objective of the firm. Instead, the firm should take into account the different stakeholders that interact with it (customers, suppliers, workers, shareholders, public administrations, local communities, society at large), each of which has its own rational objectives, and not only the shareholders' objectives (Hamschmidt \& Pirson, 2011). Other authors have pointed out that, if firms do not take all stakeholders' objectives into account, these groups will not have sufficient incentive to make a commitment to the firm, and will thereby undermine its capacity to fulfill its economic potential (Keay, 2007). 
According to some authors, one of the main tasks of the firm should be to generate value propositions that may motivate and interest stakeholders (Freeman et al., 2010). In their view, profits should be the consequence of a broad company vision, one that considers the needs of stakeholders (shareholders included) and offers value propositions that are attractive to them. Profits should not be the primary goal, but the result of a given behavior by the company (Pirson, 2014).

Moreover, this course of action would result in a more sustainable performance by the company, because it would base its value- and profit-generating capacity on nurturing its stakeholders. Instead of playing a zero-sum game with them, the firm would work in consonance with their interests in order to co-create more value for all. The overall value creation would then be greater and more sustainable. According to Porter, shared value creation would benefit the shareholders and the rest of stakeholders as well, while simultaneously improving the well-being of a larger part of society. The market economy would become more inclusive and firms would earn not only profits, but also support and legitimacy from the entire social and political systems (Porter \& Kramer, 2011). The L-K model is in line with this new view of the firm and encourages future managers to consider not only the economic sustainability of the firm, but environmental and social sustainability as well. Moreover, it makes legitimacy of the firm dependent on its commitment to the enhancement of human dignity and social well-being (Nicolás, 2011). As a result, management students at Jesuit Business Schools receive a humanistic education that stresses not only competitiveness, but environmental sustainability and social responsibility as well.

Those academics, from very diverse backgrounds, who have decided to move beyond the utilitarian or profit-maximizing approach, consider that the human person is the key element in economic activity. Thus, human dignity (and not profit maximization) should be placed at the very center of the economic system (Becchetti \& Borzaga, 2010). Dignity has been defined as "the ability to establish a sense of selfworth and self-respect and to appreciate the respect of others" (Hodson, 2001, p. 3), and, according to economic historians, throughout history, its defense and protection has been a catalyst for both social progress (the struggle for democracy, the advocacy of human rights) and economic development (which includes, among other elements, learning processes, investment and innovation) (Pirson, 2014).

Different schools of thought have developed the concept of dignity over time, and we will focus on two of them: the Kantian tradition and Catholic Social Thought. Although the CST tradition plays a major role in its final design, the L-K model incorporates insights from both approaches, with the concept of human dignity being a key element in its implementation in Business Schools (Nicolás, 2010). According to the Kantian tradition, people should be treated as ends in themselves. This means that every person has an intrinsic value that cannot be exchanged, sold or purchased by others. This intrinsic value is dignity (Pirson, 2014) and all "priceless" aspects of humankind (virtue, integrity, freedom, knowledge, wisdom, love, trust, forgiveness or gratitude) are a part of it. Catholic Social Thought claims that all human beings have dignity because they all resemble God (EoC, 2011).
They are all a part of the human family, with equal rights and duties under the commandment of love. Thus, according to modern Catholic humanism, as a result of their inviolable dignity, all persons should have access to basic social, economic and political rights, and these rights cannot be exchanged, sold or purchased by others, because they are inherent to the human person (Benedict XVI, 2009).

At the macroeconomic level, the principle of human dignity has been adopted and promoted by the United Nations Organization, at both the theoretical and empirical levels. The Millennium Development Goals and the UNDP initiative as a whole are designed to ensure that human dignity becomes a widespread reality throughout the world. At the microeconomic level, the UN has developed the Global Compact initiative, which proposes specific actions at the level of the firm aimed at protecting and promoting human dignity.

In the light of this principle, humanist authors argue that, instead of short-term profit maximization, firms should promote the common good and profits should be a consequence of this activity (Bruni \& Zamagni, 2004). Economic activities that maximize shareholder value in the short term at the expense of society will become meaningless and will cease to exist. Consequently, management theory should focus on the creation of social well-being (Pirson, 2014) and, in fact, as a result of this recent shift in economic and managerial thinking (also shared by JBSs), some corporations have started to measure their performance not only in terms of profit, but also in terms of personal and environmental impact, and the benefits yielded to local communities (Elkington, 1997).

However, one problem arises at this point. While there is a broad range of standardized and accurate indicators to measure profits, there are no comparable, systematic, accurate instruments to measure the creation of social well-being at the level of the firm. In the next section we present a model that may be used to fill this gap.

\section{A new methodological framework to assess the total (consolidated) value generated by the firm}

As mentioned above, one objective of this paper is to present a model capable of measuring the social value and the economic value generated by firms, such that society, managers and public administrations have an operational tool to present and evaluate the economic and social performance of firms.

Although at the macroeconomic level there are robust metrics and indices to measure human development (OECD, 2014), at the microeconomic level the metrics are still being developed. The triple bottom line approach (Elkington, 1997) and the Global Reporting Initiative, GRI (GRI, 2015), are two recent methodologies with this goal in mind. However, they both measure each of the three major dimensions of sustainability (economic, social and environmental) separately. In our opinion, there is still a need for a comprehensive model capable of measuring the financial and non-financial activities of the firm. In order to find a solution to this problem, the ECRI Research Group (Ethics in Finance \& Social Value, participated by researchers at the Deusto Business School and the University of the Basque Country) has developed 
a methodology based on the stakeholder theory, called the "polyhedral model" (Retolaza et al., 2014; San-José et al., 2014). This model makes it possible to identify the total value (financial and non-financial), termed the consolidated social value, that the firm generates for each of the stakeholders that interact with it (specific social value) and the consolidated value that it generates for all stakeholders (including shareholders) and society at large. The polyhedral model rests on four pillars. The first is the aforementioned stakeholder theory (Freeman et al., 2010). The second pillar is the action research approach (Lewin, 1958). The third pillar is the phenomenological perspective (Husserl, 1982), as applied to the identification of the perceived value that the firm generates for each of the stakeholders. Finally, the fourth pillar is fuzzy logic (Zadeh, 1965), which conceives value as an interval with fuzzy upper and lower limits around a subjectively chosen center.
On the basis of these four pillars, the polyhedral model proposes a six-step process to determine the consolidated social value generated by the firm (see Figure 1). The process begins when a given organization/firm expresses an interest in identifying its impact on society and accepts the polyhedral model as a valid instrument to measure its social value. The next step involves analyzing the main purpose of the firm (mission, vision, and values) and identifying its main interest groups in order to draft a full stakeholder map. The third step involves identifying the variables that generate value for the stakeholders. This is done by means of interviews and open-ended questionnaires, and a variable value matrix is then elaborated. The fourth step involves identifying valid proxies with monetary value that may allow for the quantification of the monetary value of the variables identified in the preceding step. The fifth step involves calculating the monetary value of each of the variables through their corresponding proxies.

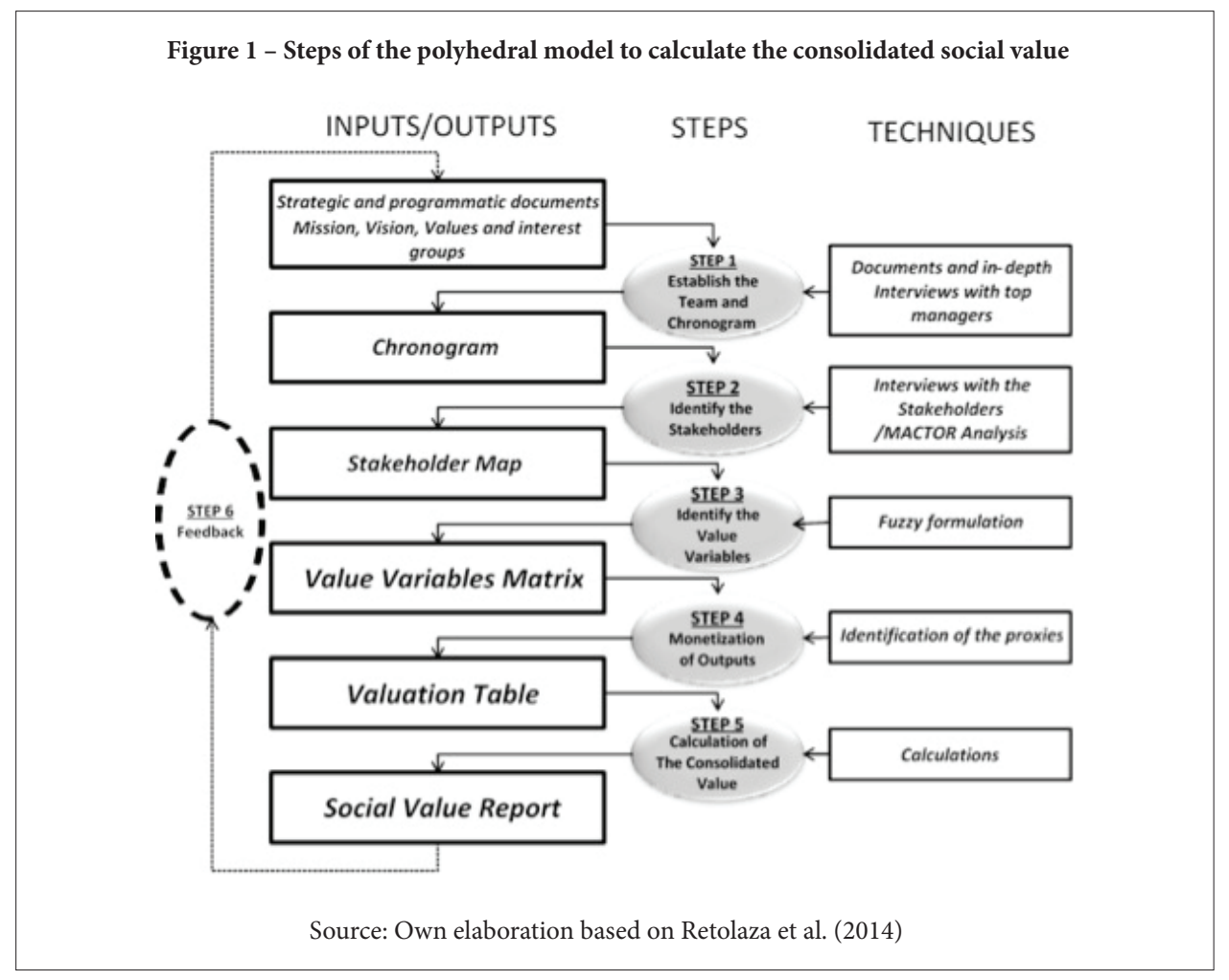

Once this step is completed, it is possible to calculate the value that the firm generates for each stakeholder, and the consolidated social value is calculated by agglomerating the value created for all the stakeholders. Finally, in the feedback step, the purpose of the firm, the stakeholder map and the entire process are reconsidered in the light of the compiled results.

This model, which is still being developed, has been used to analyze different organizations (for-profit and non-profit, private and stateowned) (Retolaza et al., 2014) and has also been applied to the financial sector in Spain (San José et al., 2014). The results from these studies allow us to conclude that the model may serve as a basis to calculate the consolidated social value generated by firms in a systematic, comparable manner, such that investors, consumers, public administrations and the wider public may make fair assessments about the social impacts of firms and their contribution to human dignity and social well-being.

\section{Conclusions}

The Ledesma-Kolvenbach model is the new model applied by the Society of Jesus in higher education. The model stresses the importance of knowing the "tools of the trade" for each profession (business education, in the case of JBSs), while simultaneously advocating justice and the intrinsic values of the human person, and providing an open window to the spiritual dimension. 
When applied to management education, this new educational paradigm is in line with the new theoretical developments regarding the goals of the firm and its role in society. In the current post-crisis scenario, firms should pay attention to their degree of legitimacy in society. Corporations that focus on short-term profit maximization and do not consider contributing to social well-being will lose the favor of consumers, public administrations and society as a whole. The L-K model educates management professionals who will be concerned not only with the economic performance of their organizations, but with their social and environmental impact as well, who will advocate human dignity and social well-being, and for whom leadership will be an opportunity to contribute to the well-being of others, and not only a way to fulfill personal ambitions.

In order to measure the performance of a firm taking into account its economic success as well as its environmental sustainability, its contribution to social well-being and its active promotion of human dignity, it is necessary to build a model capable of quantifying all these dimensions. This type of model, which was presented in the last part of this article, makes it possible to determine the total value (economic and social) generated by the firm. It takes into account the firm's impact on all the stakeholders that interact with it, and the information is displayed in a comparative, readily comprehensible manner. The future challenge for JBSs is to analyze their alumni's behavior in terms of their promotion of human dignity and their contribution to social well-being and sustainable competitiveness in the organizations that they will manage and/or create. A positive differentiation when compared to alumni from other business schools would be a strong measure of the success of the L-K model.

\section{Bibliography}

Aguado, R., Alcañiz, L., \& Retolaza, J.L. (2015). A new role for the firm incorporating sustainability and human dignity. Conceptualization and measurement. Human Systems Management, 34, 43-56.

Aguado, R.. \& Martínez, J. (2012). GDP and beyond: Towards new measurements of sustainability based on Catholic Social Thought. Asia-Pacific Journal of Business Administration, 4(2), 124-138.

Agúndez, M. (2008). El paradigma universitario Ledesma-Kolvenbach. Revista de Fomento Social, 252, 603-631.

Becchetti, L., \& Borzaga, C. (2010). The economics of social responsibility. London: Routledge.

Benedict XVI (2009). Caritas in veritate. The Vatican. Retrieved from www.papalencyclicals.net.

Bruni, L., \& Zamagni, S. (2004). The Economy of Communion: Inspirations and achievements. Finance \& The Common Good/Bien Común, 20, 91-97.
Dierksmeier, C. (2011). Reorientiring management education: From Homo Economicus to human dignity. In H.M. Network (Eds.), Business Schools under fire. New York: Palgrave McMillan.

EoC (Economy of Communion International Commission) (2011). General guidelines for operating an Economy of Communion business. Retrieved from Economy of Communion website, www.edc-online.org. Consulted on 01/10/2014.

Elkington, J. (1997). Cannibals with forks: The Triple Bottom Line of 21st century business. Oxford: Capstone Publishing.

Etxeberria, X. (2008). FIDES I: Cultivar la dimensión trascendente. Revista de Fomento Social, 252, 691-714.

Florensa, A. (2008). Humanitas: La persona en el centro del proceso de formación. Revista de Fomento Social, 252, 671-690.

Freeman, E., Harrison, J.S., Wicks, A.C., Parmar, B.L., \& de Colle, S. (2010). Stakeholder Theory: The state of the art. Cambridge: Cambridge University Press.

Ghoshal, S. (2005). Bad management theories are destroying good management practices. Academy of Management Learning and Education, 4(1), 75-91.

GRI (Global Reporting Initiative) (2015). G4 Sustainability Reporting Guidelines. Retrieved from GRI website, www. globalreporting.org/standards/g4/Pages/default.aspx. Consulted on $01 / 07 / 2015$.

Hamschmidt, J., and Pirson, M. (2011). Case studies in social entrepreneurship and sustainability. Sheffield: Greenleaf Publishing.

Hodson, R. (2001). Dignity at work. Cambridge: Cambridge University Press.

Husserl, E. (1982). La idea de la fenomenología. Cinco lecciones. Buenos Aires: FCE.

Jensen, M.C. (2002). Value maximization, stakeholder theory, and the corporate objective function. Business Ethics Quarterly, 12(2), 235-257.

Keay, A. (2007). Tackling the issue of the corporate objective: An analysis of the United Kingdom's enlightened shareholder value approach. Sydney Law Review, 29(4), 577-612.

Kolvenbach, P.-H. (2001). The Service of faith and the promotion of justice in American Jesuit Higher Education. Retrieved from the Society of Jesus website, http://www.sjweb.info/documents/phk/2000santa_clara_en.pdf. Consulted on 01/10/2014.

Kolvenbach, P.-H. (2008). Discursos universitarios. Madrid: UNIJES. Lewin, K. (1958). Group decision and social change. New York: Holt, Rinehart and Winston. 
Miralles, J. (2008). FIDES II: Creyentes y no creyentes compartiendo una misma misión. Revista de Fomento Social, 252, 715-739.

Nicolás, A. (2010). Depth, universality, and learned ministry: Challenges to Jesuit Higher Education today. Retrieved from the Society of Jesus website, www.sjweb.info/documents/ansj/100423_Mexico\%20 City_Higher\%20Education\%20Today_ENG.pdf. Consulted on $01 / 10 / 2014$.

Nicolás, A. (2011). 125 Aniversario de la Universidad de Deusto. Lección Inaugural. Retrieved from the Society of Jesus website, www.sjweb.info/documents/ansj/110909_125\%20anniv.\%20Deusto_Lectio\%20repartida.pdf. Consulted on 01/10/2014.

OECD (2014). Better Life Index 2014: Definitions and metadata. Paris: OECD.

Oraá, J. (2007). Algunas reflexiones acerca del papel de las universidades jesuíticas en la promoción de la justicia: Conferencia pronunciada en el Fórum Deusto. Estudios Empresariales, 125, 26-35.
Pirson, M. (2014). Reconnecting management theory and social welfare: A humanistic perspective. Academy of Management Proceedings.

Porter, M.E., \& Kramer, M.R. (2011). Creating shared value: How to reinvent capitalism and unleash a wave of innovation and growth. Harvard Business Review, 89(1-2), 62-77.

Retolaza, J.L., San-José, L., \& Ruiz-Roqueñi, M. (2014). Ontological stakeholder view: An innovative proposition. Global Business Review 15(1), 25-36.

San-José, L., et al. (2014). Efficiency in Spanish banking: A multistakeholder approach analysis. Journal of International Financial Markets, Institutions \& Money, 32, 240-255.

Society of Jesus (1965). Monumenta Paedagogica Societas Jesu. Rome: Society of Jesus.

Society of Jesus (2014). The promotion of Justice in the Universities of the Society. Promotio Iustitiae, 116, 2014/3.

Zadeh, L. (1965). Fuzzy sets. Information control, 8, 338-353. 